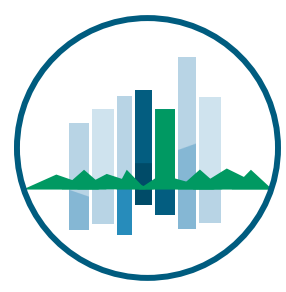

True Smart and Green City?

8th Conference of the

International Forum on Urbanism

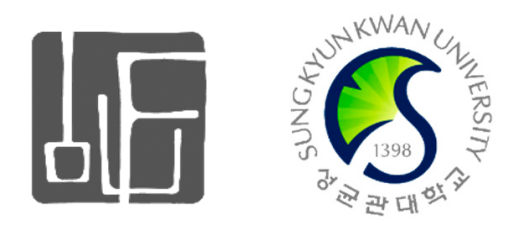

Conference Proceedings Paper

\title{
The Future of the Traditional Market and Its Importance to Develop the Global Competitiveness of the City Based on Its Local-Specific Potentials
}

\author{
Jo Santoso * and Miya Irawati \\ Tarumanagara University, Indonesia \\ * Author to whom correspondence should be addressed; E-mail: josantosojkt@yahoo.com
}

\begin{abstract}
The majority of the world cities is concentrated its effort to increase their competitiveness on global level. In the same time these cities are confronted with similar and comparable challenges, including increases in resource consumption, mobility demand, pollution, urban sprawl, social inequities, depletion of ecosystems and decreasing of the local economy, both on urban and regional level. However, specific basic conditions, as level of urbanization and relation of the city to globalized economic system require specific approaches to develop appropriate strategies to secure the long term resilience of the city. Economically globalized city like Jakarta is in increasing pressure to upgrade its competitiveness. During the last two decades many different approaches, methods, technologies and systems have been developed to facilitate the realization of city competitiveness on global market, but the majority of the approaches is generally not integrated in the overall strategy to support a sustainable future of the existing urban system. The paper observes to show the important roles of city's traditional markets as an important urban element. Using the case of some traditional markets in Jakarta, this paper the general characteristic of traditional market in Jakarta as an economic urban entity to solve their problems, create job and opportunity for migrants and lower class, and also provide needs of city population at affordable price. There have been existing innovations and initiatives of main players of traditional markets and also their synergized social network, which are beyond a survival way. The traditional markets in Jakarta have an important role for provision of social culture interaction among city residents. The research for this paper was carried out through observation, field survey and in-depth interviews as main data collection. The results of the study demonstrate the potentials of urban traditional market to relate with sustainable urban development and to finally contribute to the understanding of how traditional markets could be creating innovations based on their knowledge resources
\end{abstract}


in line with their social value system and local knowledge. The system of city's traditional market becomes an instrument of resilience urban system and expose how the system is working based on knowledge resource, local knowledge and social value system of city's traditional market in Jakarta.

\section{Introduction: The Need for Repositioning of the Traditional Market - The Case of Jakarta}

According to the concept of human habitat the traditional market is a part of the urban facilities, which provide the inhabitants with everyday consumer goods. In the same time these neighbourhood markets have the function as market place for the agrarian products from the rural hinterland such as different kind of meat, vegetables, fruits, etc . At the latest since the 1970-ties as the greater cityregion of Jakarta so called Jabodetabek was systematically transform as "growth machine", the relevance of this traditional market to provide the inhabitants with goods needed for everyday life is decreasing. In the concept of neoliberal-oriented development local-traditional markets should be transfer to a modern market and integrated to the global free-market. In case of Jakarta this leads to the substitution the local traditional products through products of food industry and imported agrarian products.

Figure 1. Location of Traditional Market according to its Typology.

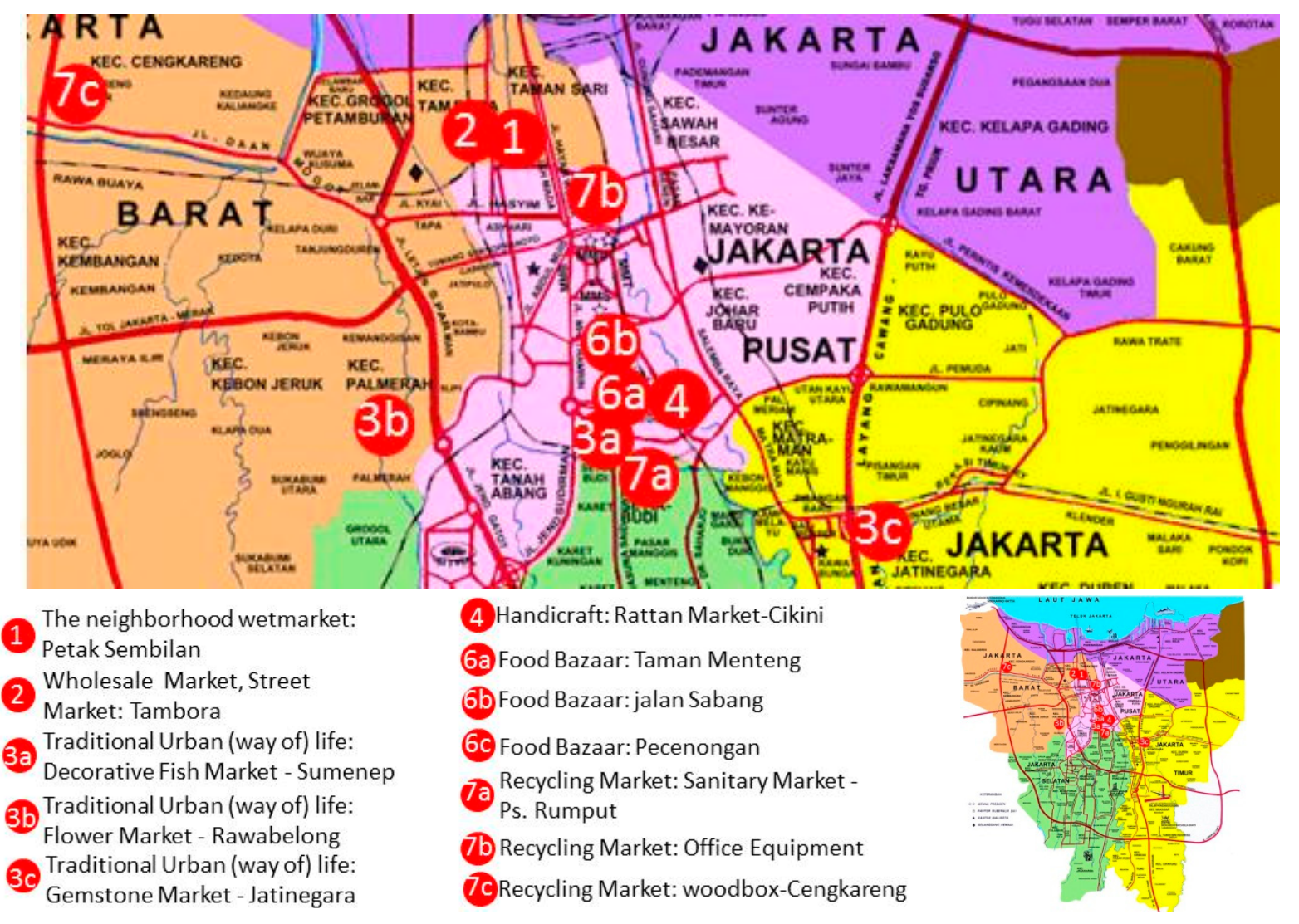

The discussion on the future of traditional market in the Globalized city like Jakarta has its relevance because of the following reasons: 1) The relevance of the traditional market is especially important firstly in relation to its function as marketplace for the products of traditional handicrafts 
and agrarian products of the small farmers in the hinterland, 2) secondly as business locations for the mini and small entrepreneur which are in the same time creating job opportunities for new coming migrants, and 3) finally the traditional market has an important role for the livelihood of the majority of the inhabitants because it supplies them with everyday goods and services with more affordable prices. Their products and services are not limited to what needed by the majority of the inhabitants to survive but furthermore also important for existence of the local specific of urban way of life of the inhabitant.

A number of factors is important in the determining the future roles of these traditional markets; the government policy is one of them, especially in relation with the equitable distribution of the urban resources such as urban space, water, and accessibility to urban services like transportation. This finding has several consequences for the city governance, that the mainstream policy of "modernization of the traditional markets" must be substitute with a new urban policy based on providing them with urban spaces and resources to develop its own interpretation of urban way of life, with the traditional market as one its integrated urban element.

\section{The Typology of Traditional Markets}

\subsection{The neighbourhood wet markets: e.g. Petak Sembilan Market}

In each neighbourhood the city government (cq Market agency) provided the inhabitant with a neighbourhood market. Its number is about 300 in the whole city. Since the expansion of the supermarket and hypermarket included Lotte and Carrefour, these neighbourhood markets have lost its competitiveness. Some of them are degraded and the government often using as argument to privatized the market. The privatization has the impacts in the marginalization small and micro traders and the exclusion of product of small home industry because the private management prefer to be supplied by the big agrarian and food industries.

Figure 2. Petak Sembilan Market.

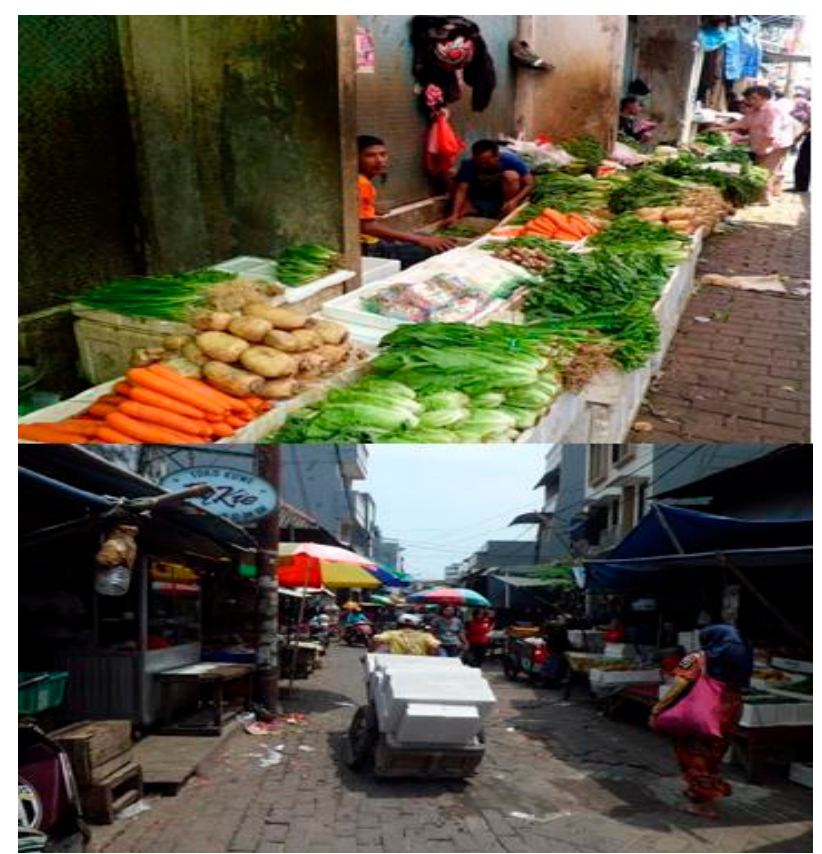




\subsection{Wholesales market: e.g. Vegetable Wholesales Market Tambora}

Originally was set up as alternative wholesales vegetables market for the north Jakarta because the official wholesales located far away in the east part of the city. The night market started at $5 \mathrm{pm}$ and is partly using parking space of the official neighbourhood market and partly the frontage of the shops after they are closed. Within more than 10 years the Tambora vegetable market became socially and economically establish but not legally.

Figure 3. Vegetable Wholesales Market Tambora.

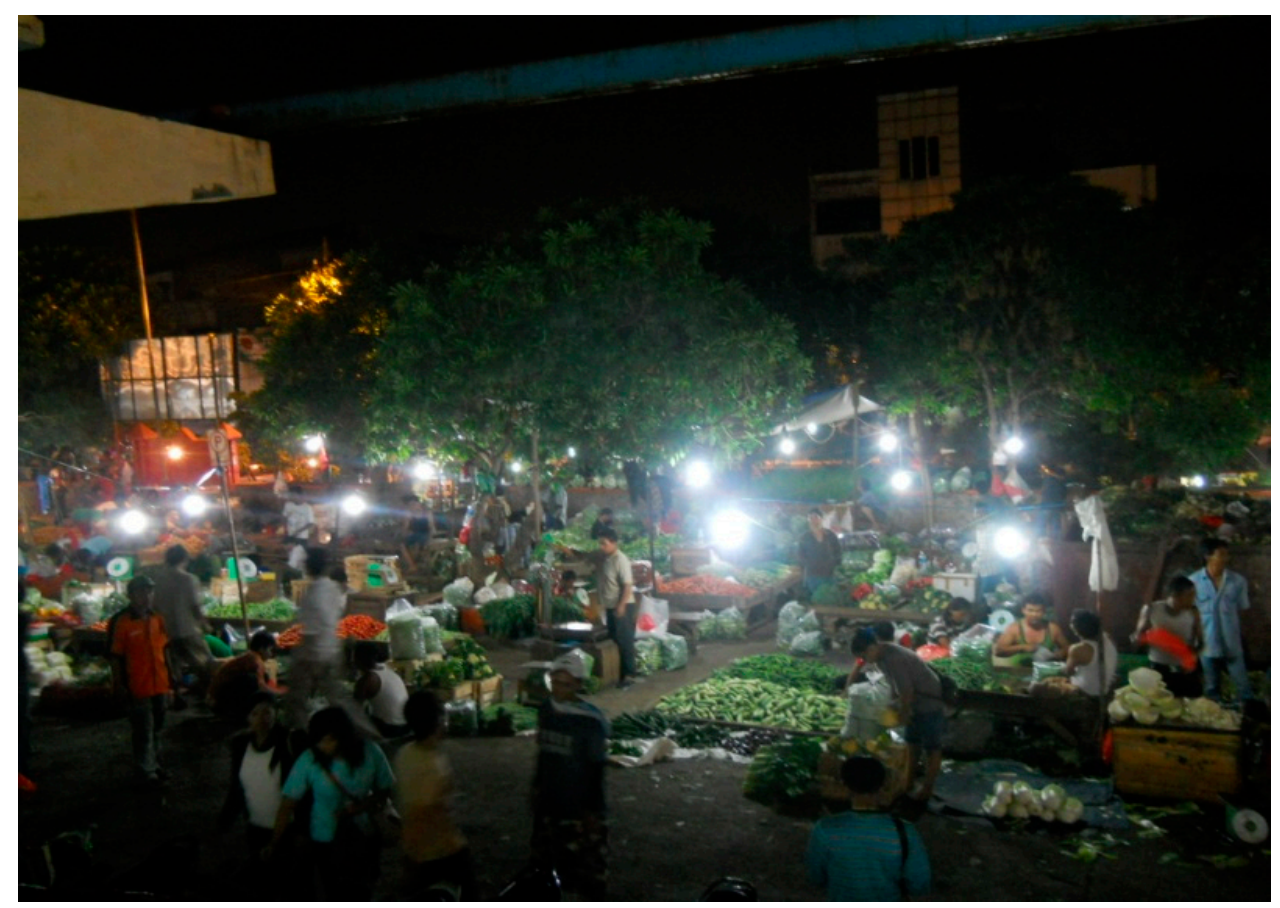

2.3 The traditional Urban (way of) Life Market: Decorative Fish Market, Flower Market, Bird Market and Gemstone Market

The existence of these markets are strongly related to the traditional way of life, partly originated in the pre-colonial culture like Gemstone market, Bird market, partly established during the colonial period like decorative fish market or flower market. In case of Gemstone the love to wear gemstone ring or to have singing birds as house animals rooted in thousand years of old tradition. In the last decades the wearing gemstone ring was becoming a fashion strong influenced by the previous president Yudhoyono who loves to wear gemstone ring.

In the local tradition fish is not only for aquarium but there is a strong tradition of animal fighting like cook fighting and fish fighting, which were related to tradition of gambling. Flower culture was elaborated most in the modern colonial period as the Dutch has introduced to use flowers as part of everyday culture. Before those flowers was using only related to ritual occasions like wedding or interment. 
Figure 4. The traditional Urban (way of) Life Market.

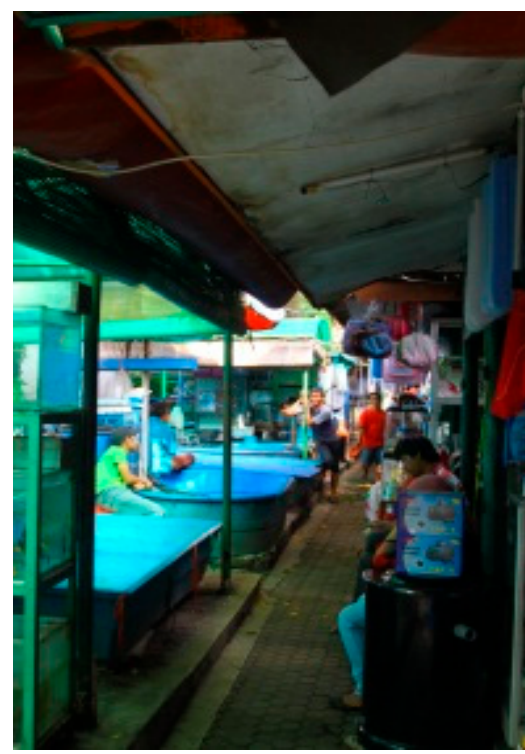

Decorative Fish Market

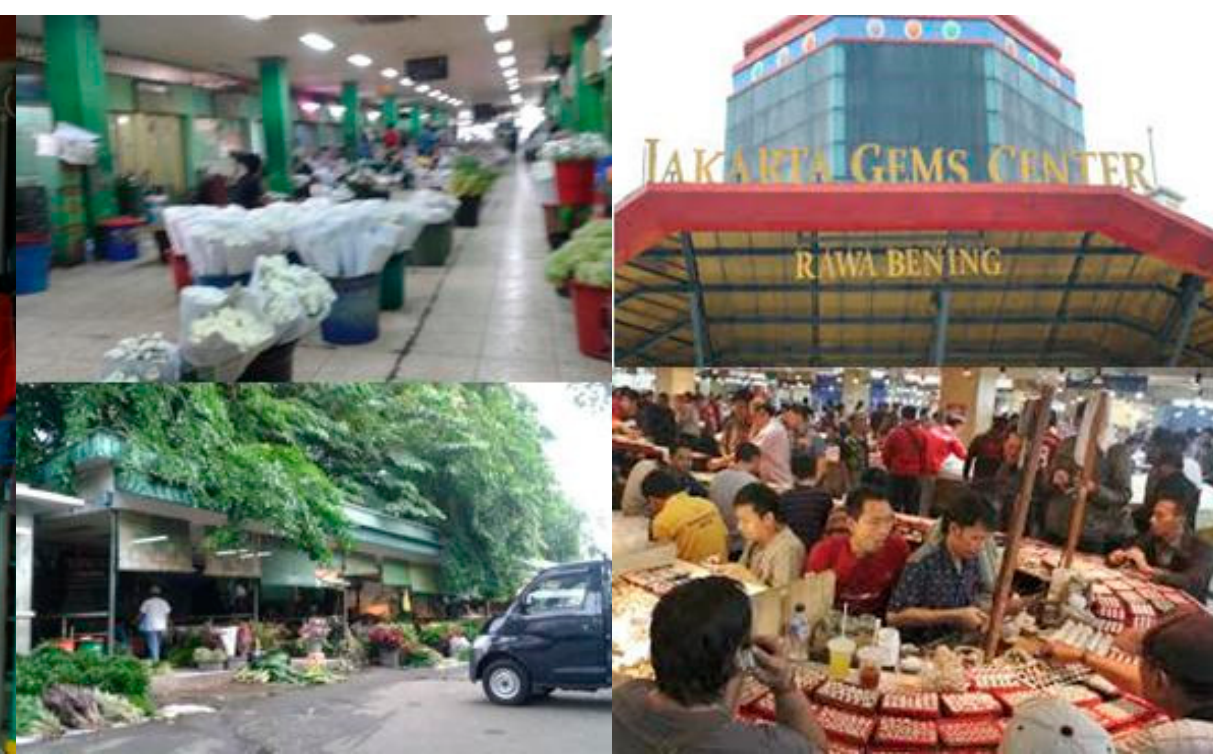

Flower Market

Gemstone Market

\subsection{Handicraft: Rattan Market, Bamboo and Wood Furniture Market}

Similar to the flower culture is almost the whole handicrafts, which are producing household articles from bamboos, wood or rattan is in fact originated from local pre-colonial tradition. A further development base on the tradition is in the 1980ties with the production of furniture from the traditional materials. Today furniture from bamboos and rattan are worldwide well known and it has its fanatic lovers.

Figure 5. Rattan Market in Cikini.

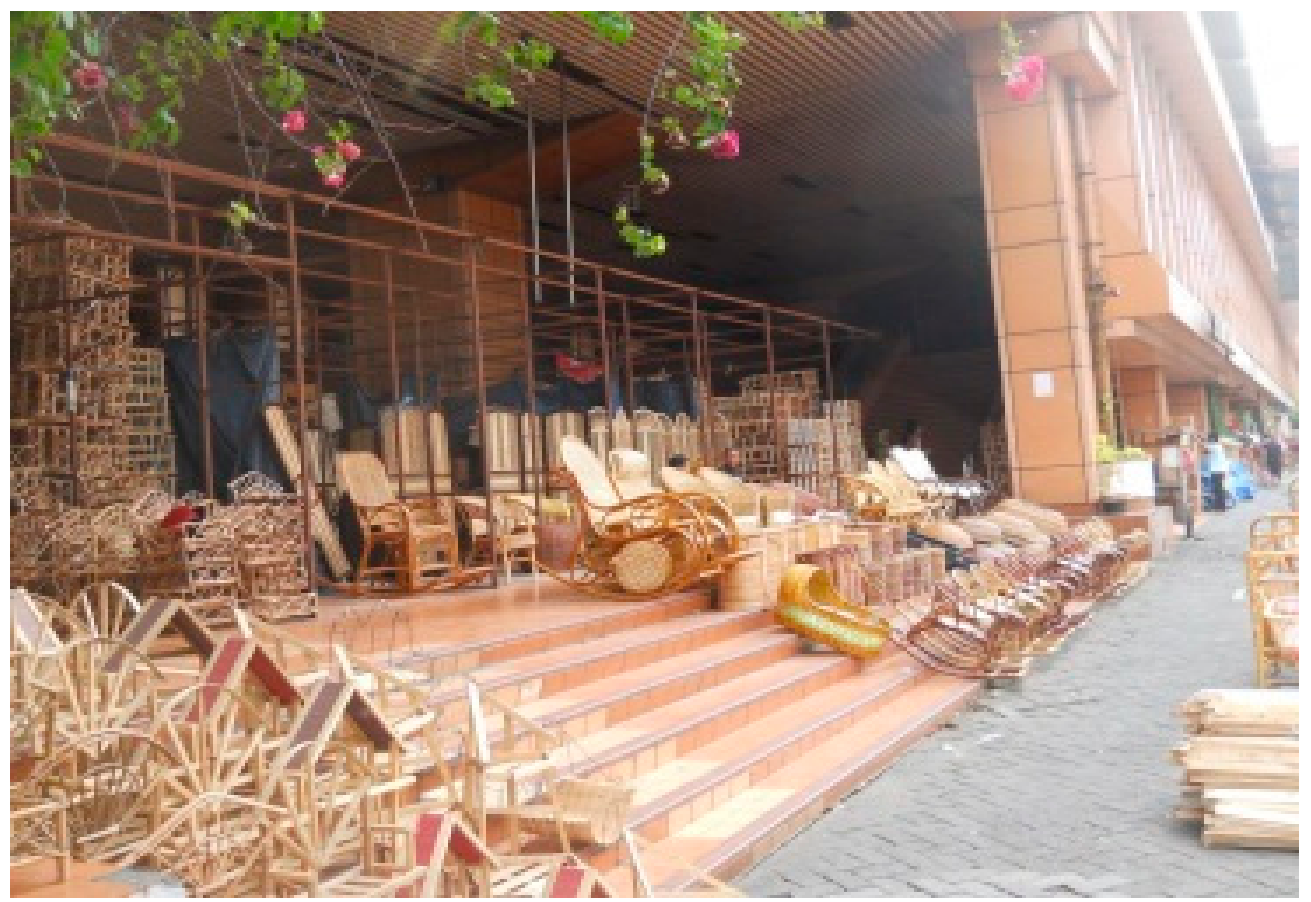




\subsection{Consumer goods street market: extended Tambora Night Market, Teluk Gong Night Market}

The number of these kind of street market is from all the traditional markets is without any doubt the highest one, they are spread all over the city, where ever it is possible to get locations, in every corner of the road, in frontage of shop housing, in open space, mostly illegal or at least halflegal. Their locations are usually oriented to the surrounding areas of high density urban kampongs because a big percentage of their clients are the inhabitants of such kampongs.

Figure 6. Extended Tambora Night Street Market.

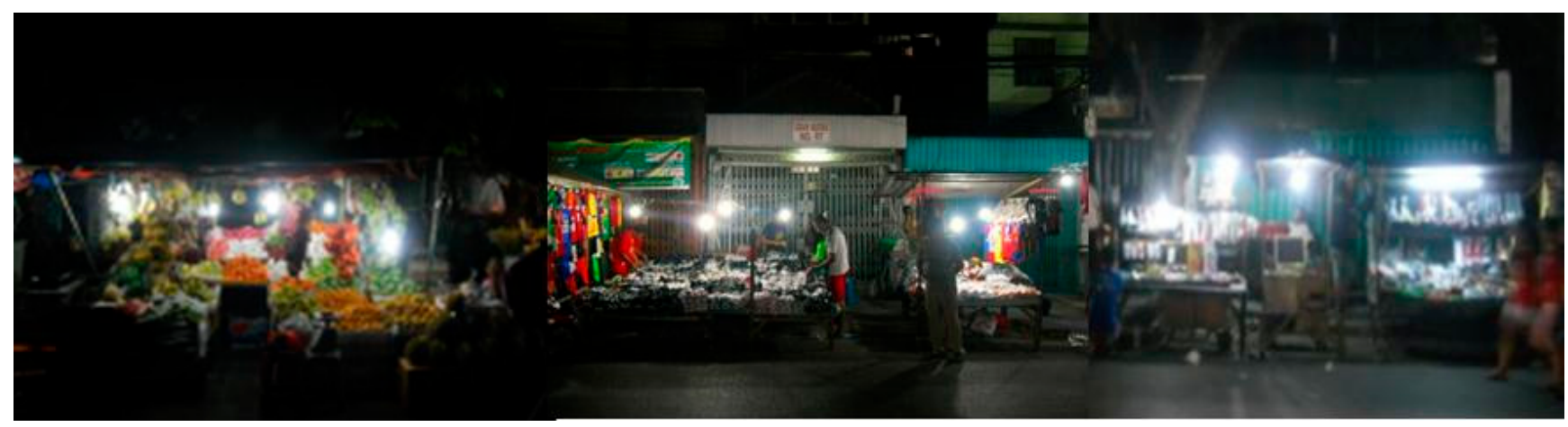

\subsection{Food Bazaar: Taman Menteng, jalan Sabang, Pecenongan}

The traditional food bazaar has specific clients, most of them targeted lower income working in offices. A small number of them is opening in the evening hours and become a popular eating place for young peoples and lower incomes families. Some of them are popular for its special characters like chienese food in pecenongan, Grilled Seafood in Gunung sahari, Grill chicken spear in J1.Sabang or West-Sumatra Food in Kramat.

Figure 8. Food Bazaar in Jakarta.

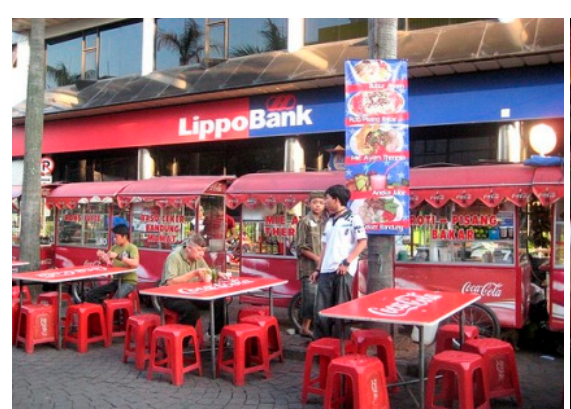

Taman Menteng

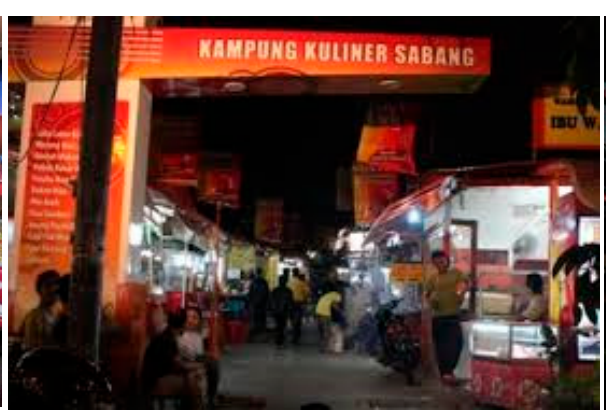

Jalan Sabang

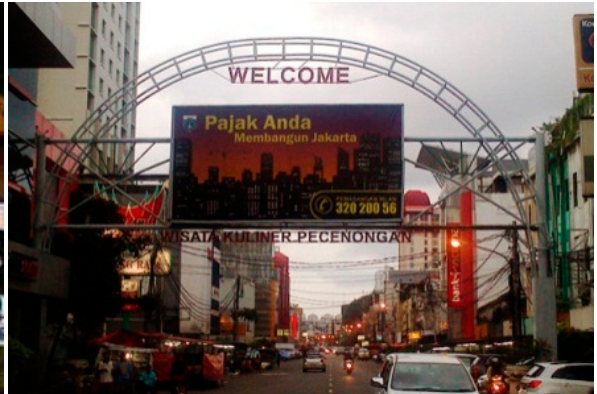

Pecenongan

2.7 Recycling Market: the Woodenbox market in Cengkareng, the office equipment), the secondary building Materials.

Some people from particular ethnic take opportunity by recycling material. There are the secondary sanitary market in Pasar Rumput, the secondary office equipment in Alaydrus and Saharjo and the woodenbox market in Cengkareng area. Their market usually low income people or small business.

Secondary Sanitary Market 
Figure 9. Type of Recycling Market in Jakarta.

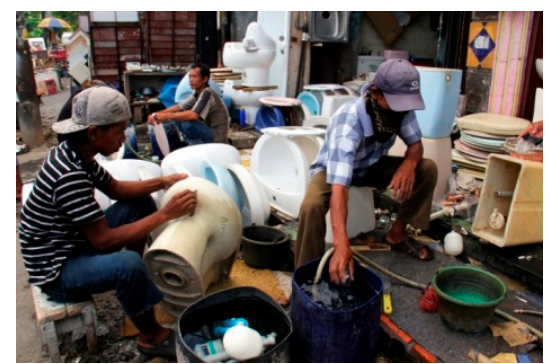

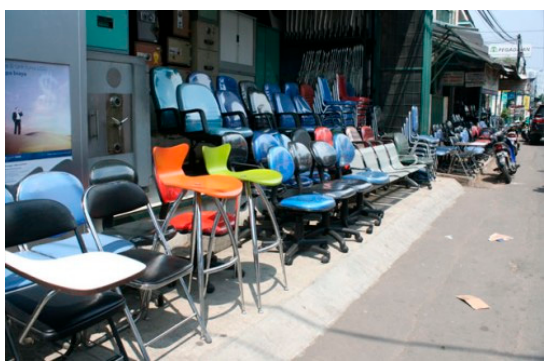

Office Equipment

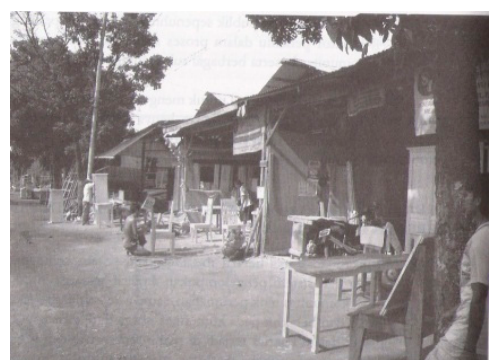

Production and Market place of Furniture with Recycling Wood panels

\section{General Characters of Traditional Market}

\section{a) Permanent Insecurity}

In term of legal status the existence of traditional markets can be differentiated into a wide range of variation form a relatively strong to an almost without any legal guarantee. The strongest status a micro or small trader in a traditional market if they have been registered as a formal tenant in a government owned traditional market.

In many cases there is only a kind of "contract" between a group of vendors with the management of the market. In this case the individual trader does not have a legal status, because the group itself is in fact an informal organization. Obviously the character of the membership of each individual trader in this informal group does not have a legal status.

On the other side even the so call illegal markets have many forms in terms of legality. In many cases the vendors have only a kind of individual permit from the owner of the property. In part of Tambora market or Pecenongan Food Bazar the vendors are using the frontage of private property like shop houses and they have only a kind of individual informal permit. Sometime the status of the permit can be upgraded to an informal contract between a group of trader with the neighbourhood blockward (the head of Rukun Warga/ RW). In case of Pecenongan the local government has given indirect support to the whole process by declaring this area officially as centre of culinary of Jakarta.

Figure 10. Legal Traditional Markets which are Provided by City Government.

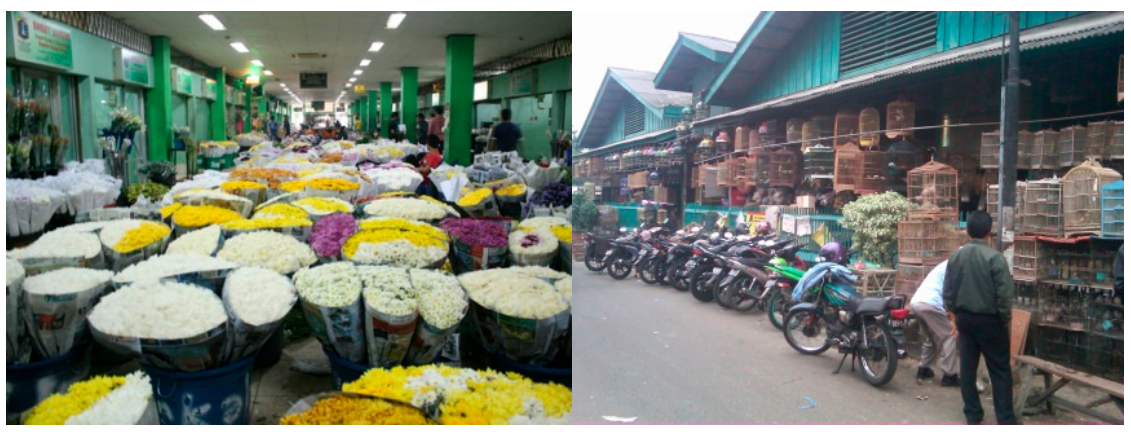

The Flower Market
The Bird Market

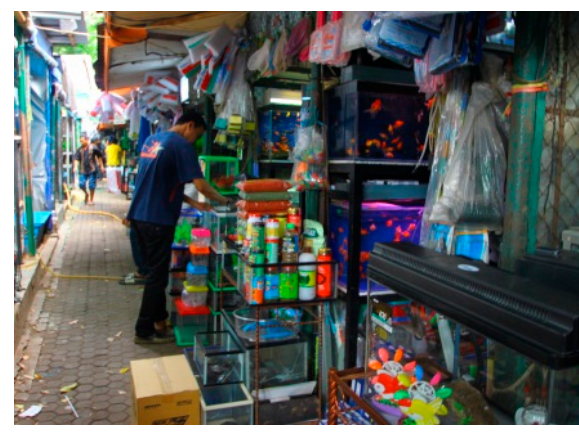

The Fish Market

In general we still can say that all traders or even the existence of the traditional market itself is always attended by a kind of insecurity (Simone). In the reality even a very strong legal status can't give 
the trader a $100 \%$ guarantee that they can stay forever in that particular market. This is happen usually as the city government decided to modernize the traditional market. In a number of redevelopment we can find many cases that the original traders with strong legal status are being marginalized through "market mechanism" because other vendors are ready to pay more.

Figure 11. Market with Permanent and Half Illegal Status.

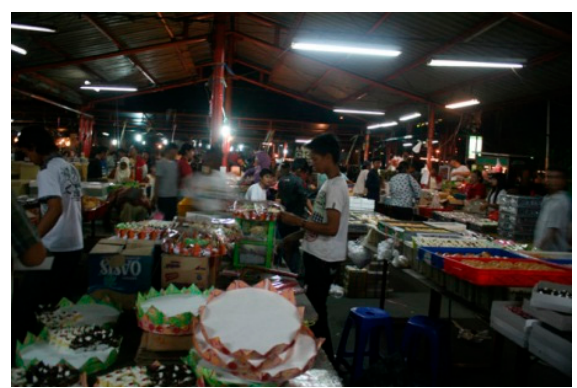

The Snack \& Cookies Market

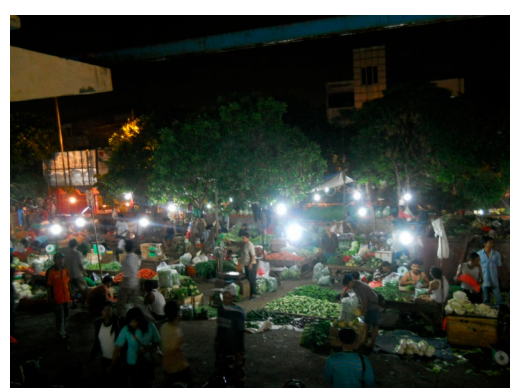

Tambora Wholesale Vegetable Market

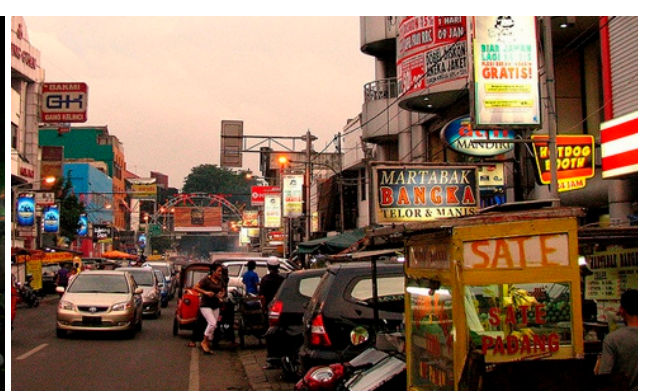

The Food Bazaar in Pecenongan

Figure 12. Market With Illegal Status.

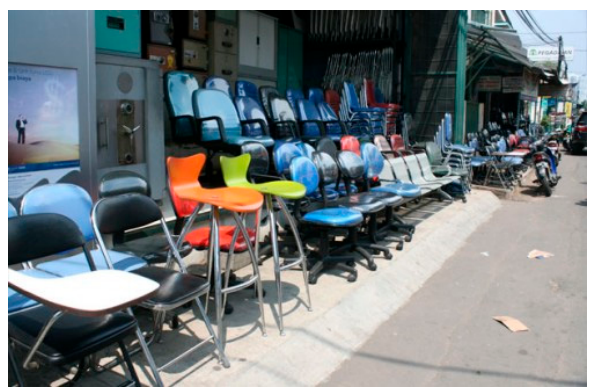

The Recycling Office Equipment

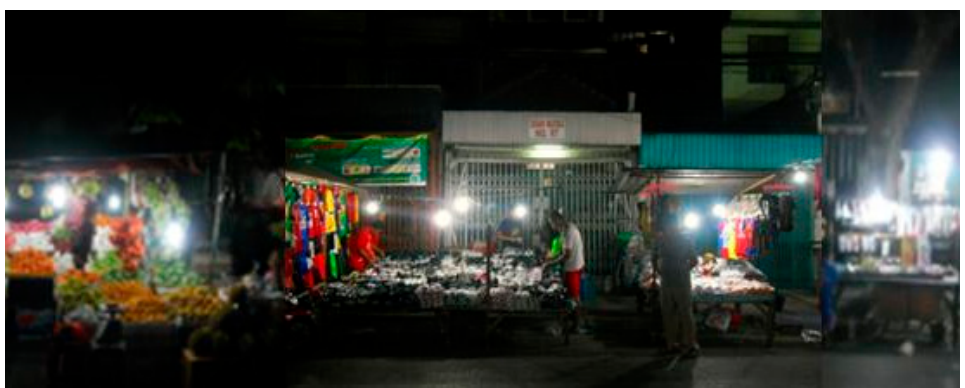

The Extended Night Street Market In Tambora

\section{b) As Locations for Micro and Small Entrepreneur}

The traditional market give job opportunities/ or lowest entre barrier for migrants. Below are the list of number of vendor and also number of their employee who is helping their business. Most of the employees are their family (brother/ sister, couple, neighbor in their village).

\section{c) As Cultural institutions support local specific way of life/ social relationship.}

The existence of the traditional market as an cultural institution is behind the urban kampong and it's the most important heritage of the pre-colonial urban culture. Its social or cultural relevant are not always tangible. The social relationship occurs because of their same interest. Traders and also the gemstone lovers, birds lovers, decorative fish lovers are coming from different ethnic.

Through culinary food bazaar, people from different ethnic know each other and learn about other culture. In Pecenongan food bazaar, everybody can try different kinds of Chinese food included the halal one. Also the visitors of Padang food are from all kind of ethnic-origin. The best example for the integrated cultural process behind the adapted traditional market is: The Snack and Cookies market. Here you can find Cookies and snack from different ethnical origin in one roof. 
Table 1. The number of Vendor and Their Employees in Traditional Market.

\begin{tabular}{|l|c|c|}
\hline Market & $\begin{array}{c}\text { Number of } \\
\text { vendors (person) }\end{array}$ & $\begin{array}{c}\text { Number of } \\
\text { employee } \\
\text { (person) }\end{array}$ \\
\hline The Wholesale Vegetable Market in Tambora & 216 & $400-450$ \\
\hline $\begin{array}{l}\text { The extended Night Street Market in } \\
\text { Tambora }\end{array}$ & 201 & 300 \\
\hline $\begin{array}{l}\text { The Snack and Cookies Market in Senen (2 } \\
\text { shifts) }\end{array}$ & 1300 & 2500 \\
\hline $\begin{array}{l}\text { The Flower Market } \\
\text { The Bird Market }\end{array}$ & 272 & 300 \\
\hline The Fish Market & 95 & 300 \\
\hline
\end{tabular}

(Source: Mapping by Authors)

Figure 13. The Snack and Cookies Market as the Best Adapted Market for the Integrated Cultural Process.
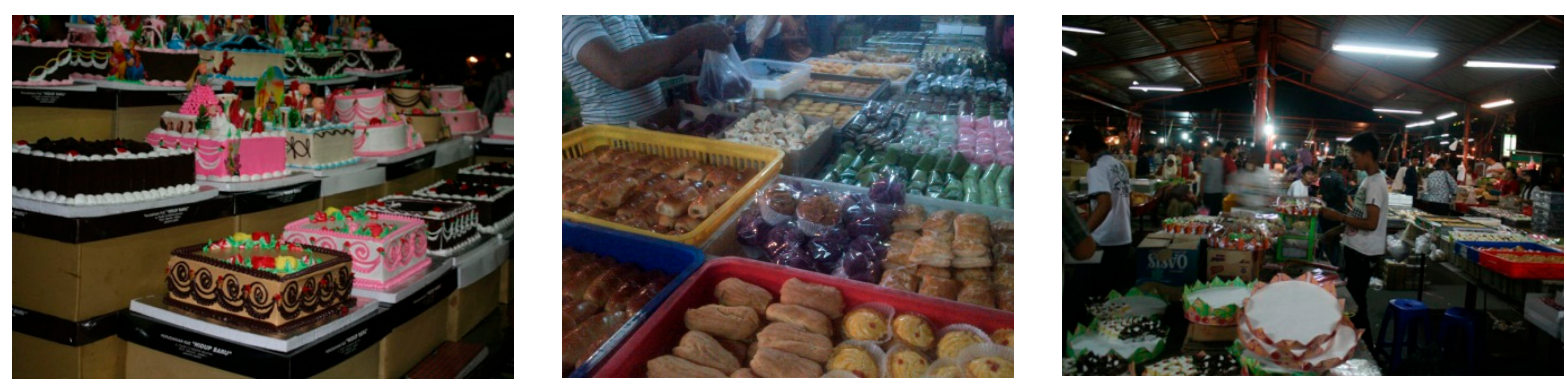

People from different ethnic and religions are coming to the type of market then learning from each other. They learn to love other kind of values, other kind of aesthetic, other kind of taste. They react on that then have their interpretation and give their comments.

\section{Conclusion and Recommendation}

The conclusions of this paper are:

1. Traditional markets has contributed greatly to the town, which are 1) creating jobs for the migrant, 2) providing opportunities for micro and small enterprises to survive, 3) offering the needs of city dwellers with affordable price, especially for the lower economic society

2. By changing the traditional markets into a market with modern structures is a mistake. It is not going to be implemented in Jakarta. There were some examples of it.

3. Unavailability of permanent security for all traditional markets in Jakarta. Many sellers in many traditional markets have to survive together with their group to obtain a place for existence and earning money.

4. Traditional market is also an important urban element which is a place of interaction for multi culture (social relationship) to know and learn each other. 
The recommendations are:

1. The city government must change policy that does not change the model of the traditional market into the modern market.

2. The city government can maintain and develop modern policy which helps micro and small traders/ enterprise by providing loans/ micro finance.

3. The city government serves as facilitator in which not only allow the traditional markets, but also provide space, utilities (water, electricity, waste management) and appropriate transportation for the actors of the traditional markets, especially its traders.

\section{References}

Ancien, Delphine 2011 Global City Theory and the New Urban Politics Twenty Years On. Urban Studies 48: $2473-2493$.

Angel, S., (2012) Planet of Cities, Cambridge.Massachusetts.

Agyeman, J.,Bullard, R. D.,Evans, B. (2003) Just Sustainabilities - Development In An Unequal World, London.

Barker, Joshua 2009 Negara Beling: Street-Level Authority in an Indonesian Slum. In. G. Bayat, Asef 2009 Life as Politics: How Ordinary People Change the Middle East. Stanford, Ca.: Stanford University Press.

Brenner, Neil 2004 New State Spaces: Urban Governance and the Rescaling of Statehood. Oxford and New York: Oxford University Press.

Bunnell, Tim and Anant Maringanti 2010 Practicing Urban and Regional Research beyond Campbell, S., S.Fainstein, S., (2002) Reading in Urban Theory, Oxford (2003), Readings in Planning Theory, Oxford.

Colombijn, F., (2010), Under construction: The politics of urban space and housing during the decolonization of Indonesia, 1930-1960. Leiden: KITLV Press.

Cowherd, R., (2002) Planning or Cultural Construction? Local and Global Forces in the Transformation of Jakarta. In: Peter J.M. Nas (ed.) The Indonesian Town Revisited. Muenster: LIT Verlag, 17-40.

Devisari, T., (2008), Spatial Economy in the Urban Informal Settlement, Casestudy Jakarta, TU Delft.

Dick, H.W., Rimmer, P., (1998), Beyond the Third World City: The New Urban Geography of Southeast Asia, Urban Studies, 35, 12, 1998: 2303-2321.

Firman,T., (2004), New Town Development in Jakarta Metropolitan Region: A Perspective of Spatial Segregation, Habitat International 28, 3, pp. 349-368.

Friedmann, J., (2007) The Wealth Of Cities - Toward An Asset-Based Development Of Newly Urbanizing Regions, UN-HABITAT Nairobi.

(2011), Insurgencies: Essays in Planning Theory, Routledge, p.15-16 Harvey, D. (1993) Social Justice, Postmodernism and The City, in: International Journal of Urban and Regional Research 16, $588-601$.

R. Jochimsen (1966), Theorie der Infrastruktur, Grundlagen der marktwirtschaftlichen Entwicklung. Tübingen, J.C.B. Mohr (Paul Siebeck). 
Kusno, A. (2012), Rethinking the Nation, in: Greig, C.C., Cairns, S., and Heynen H., The SAGE Handbook of Architectural Theory, pp. 213-230.

Lefebvre, H.(1991), The Production of Space, Blackwell.

Logan, J.R., Harvey L., M., (1987) The City as a Growth Machine, in: Fanstein, S., S., Campbell, S.,19 (2002), Readings in Urban Theory, p.199-238, Blackwell.

Marcelloni, M., (2007) The Challenge of Governing the New Scale of the Contemporary City, in: Rosemann, J., (2007) Perma City, pp.223-227.,Delft.

Robinson, J., 2002, “Global and World Cities: A View from Off the Map," International Journal of Urban and Regional Research, 26, 3, 2002: 531-554. who criticizes globalizing theorists and calls for an examination of ordinary spaces of the city.

Read, S. (2007), How do we begin to understand local places in a global world?, in: Rosemann, J.,(2007), Perma City, Delft.

Miles, M, Miles, S., (2004) Consuming City, Palgrave.

Santoso, J., (2007) Rethinking the Concept of Sustainable Urban Development: The Case of Greater Jakarta, In: Rosemann, J., (2007) Perma City, Delft, pp.301 -305. (2010), The Fifth Layer of Jakarta, Centropolis Tarumanagara. The Present Of Local Specific Culture In The Future-Globalized Cities - The Case Of Local-traditional Markets of Jakarta, in: Proceeding of IfoU Conference in Tainan 7th -11 th October 2013, organized by NCKU-Taiwan.

Saskia, S., (1990) The Changing World Economy and Urban Restructuring, in: Fanstein, S., S., Campbell, S., (2002) Readings in Urban Theory, p.32-56, Blackwell.

Simone, A.M., (2010), City Life from Jakarta to Dakar, 263 pp.

(2012), Introduction:Enacting Modernity, in: Greig, C.C., Cairns, S., and Heynen H., The SAGE Handbook of Architectural Theory, pp. 201-212.

Simone,A., M.,and Rao (2012), "Securing the Majority: Living Through Uncertainty in Jakarta," International of Urban and Regional Research, 36, 2, pp. 315-335.

Marcuse, P., van Kempen, R., (2000) Globalizing Cities: A New Spatial Order, Oxford. Myrdal, G., (1957) Economic Theory and Underdeveloped Regions, Gerald Duckworth, Young, I.M. (1990) Justice and the Politics of Differece, Princeton University Press/ 